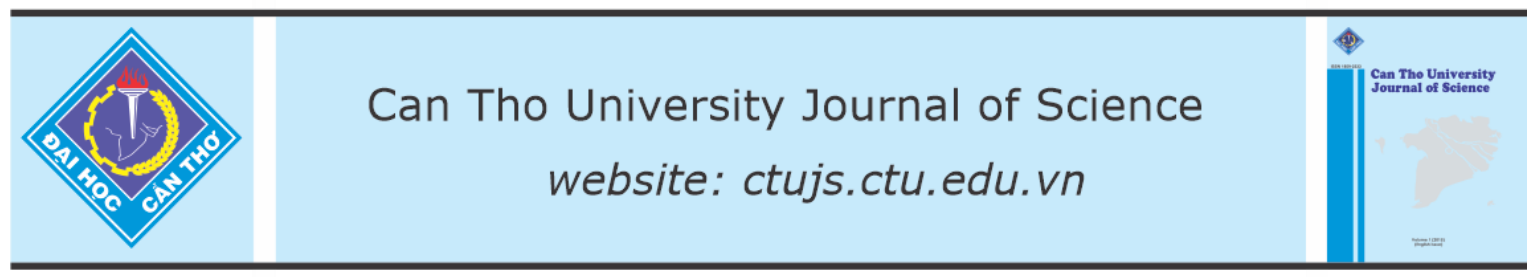

DOI: 10.22144/ctu.jen.2021.042

\title{
Chemical composition and antioxidant activity of Psidium guajava L. leaves
}

\author{
Le Thi Bach ${ }^{1}$, Le Tien Dung ${ }^{2}$, Nguyen Trong Tuan ${ }^{1}$, Ho Thanh Binh ${ }^{1}$, Do Xuan Canh ${ }^{1}$, Lam Chan \\ $\mathrm{Du}^{1}$, Bui Ngoc Anh ${ }^{1}$, Nguyen Hoang Thien Long ${ }^{1}$, Tran Nguyen Gia Huy ${ }^{1}$ and Bui Thi Buu Hue ${ }^{1 *}$ \\ ${ }^{l}$ Department of Chemistry, College of Natural Sciences, Can Tho University, Viet Nam \\ ${ }^{2}$ Institute of Applied Materials Science, Vietnam Academy of Science and Technology, Viet Nam \\ *Correspondence: Bui Thi Buи Hue (email: btbhue@ctu.edu.vn)
}

\section{Article info.}

Received 14 Apr 2021

Revised 17 Jun 2021

Accepted 24 Jun 2021

\section{Keywords}

Psidium guajava L., flavonoid, phenolic compound, antioxidant activity

\begin{abstract}
Guava, Psidium guajava L., is well-known tropic tree which is abundantly grown for fruit. It belongs to phylum Magnoliophyta, class Magnoliopsida and Myrtaceae family and has been found a lot in the Mekong Delta of Viet Nam. Antioxidant activity of different extracts from Psidium guajava $L$. leaves revealed that ethyl acetate and $n$-butanol extracts have the good activities. Processing of these fractions using repeated column and thin layer chromatographic techniques resulted in the isolation of four compounds, which have identified their chemical structures by spectroscopic techniques including avicularin (1), kaempferol (2), gallic acid (3), and protocatechuic acid (4). All the isolated compounds showed antioxidant activity using DPPH and ABTS scavenging assays. These results suggest that the leaves of guava would be useful natural sources of antioxidants.
\end{abstract}

\section{INTRODUCTION}

Vietnamese traditional medicine plays a major role in the healthcare system and many of plants, especially those found in the Mekong Delta, have been proved to possess medicinal functions. Among them, Psidium guajava L., a species belonging to the Myrtaceae family, has been found to be rich in nutrients, including vitamins and minerals that are significant for human health (Barbalho et al., 2012). The leaves of Psidium guajava L. are found to contain flavonoids, polyphenols, tannins, glycosides and terpenoids (Naseer et al., 2018; Biswas et al., 2013). It has been used traditionally as a medicinal plant throughout the world for a number of ailments. Guava extracts have the potential to act as powerful antioxidants against hepatic diseases as well as cancer. The vitamins present in guava help the body improve immunity (Ngbolua et al., 2018). There were several researches on pharmaceutical application of Psidium guajava such as antiinflammatory, antifungal, antibacterial, antidiarrheal, antioxidant, antidiabetic effects (Rawi et al., 2011; Mahfuzul et al., 2007). Therefore, in this study, the antioxidant activity of fractionated extracts and chemical investigation have been studied.

\section{EXPERIMENT}

\subsection{Chemicals and instruments}

Solvents utilized including $n$-hexane, chloroform, ethyl acetate, $n$-butanol, methanol (purity $\geq 99.0 \%$ ), and ethanol $96 \%$ were purchased from Chemsol company (Viet Nam).

NMR spectra were recorded on a Bruker AM500 FTNMR spectrometer (Bruker, Karlsruhe, Germany) using TMS as an internal standard, Institute of Chemistry - Vietnam Academy of 
Science and Technology, Hanoi, Viet Nam. TLC was performed on silica gel $60 \mathrm{~F}_{254}(0.063-0.200$ $\mathrm{mm}$, Merck, Germany). The zones were detected using UV at 254 or $365 \mathrm{~nm}$ or a solution of $\mathrm{FeCl}_{3} / \mathrm{EtOH}$ or $\mathrm{H}_{2} \mathrm{SO}_{4} / \mathrm{EtOH}$. Column chromatography was performed on silica gel (240430 mesh, Merck, Germany), ODS (70-230 mesh, Merck, Germany), and Sephadex LH- 20 (GE Healthcare Bio-Sciences AB, Uppsala, Sweden).

\subsection{Sample treatment and preparation}

The leaves of Psidium guajava L. were collected in August 2020 from Vinh Long city and authenticated by Dr. Dang Minh Quan. A voucher specimen is kept at the Department of Biology, School of Education, Can Tho University, under the number: Psi200920.

The sample was then washed away from muds and dust; the rotten and damaged parts were also discarded. The raw materials were left to dry in the shade at room temperature for some days and then dried in an oven at about $50^{\circ} \mathrm{C}$ until well-dried.

\subsection{Extraction and isolation}

The well-dried leaves of Psidium guajava L. were ground into powder $(5 \mathrm{Kg})$ which was then soaked in $96 \%$ ethanol at room temperature for four times $(4 \times 20 \mathrm{~L})$ and filtered. The filtrate was concentrated under reduced pressure to give brown residue as crude ethanol extract (500 g). This crude extract was then extracted on flash column chromatography successively with $n$-hexane, ethyl acetate, $n$ butanol, and methanol, respectively to yield the corresponding extracts of $n$-hexane $(110 \mathrm{~g})$, ethyl acetate $(75 \mathrm{~g}), n$-butanol (145 g), and methanol extract $(152 \mathrm{~g})$.

The ethyl acetate extract was subjected to flash column chromatography (CC) on silica gel and eluted with various proportions of $n$-hexane and ethyl acetate (eluting with a linear gradient from 100:0 to 0:100, v/v) to obtain 15 fractions (EE1-15).

Fraction EE5 was further separated on a silica gel column, eluted with $\mathrm{CHCl}_{3}: \mathrm{MeOH}$ (from 50:1 to $1: 1, \mathrm{v} / \mathrm{v}$ ) to yield eight subfractions (EE5.1-8). Finally, compound 1 (50 mg) was obtained from subfraction EE5.6.

Fraction EE6 was separated by a silica gel column and eluted with $\mathrm{CHCl}_{3}: \mathrm{MeOH}$ (from 50:1 to 5:1, $\mathrm{v} / \mathrm{v})$ to yield 11 subfractions (EE6.1-11). Subfraction EE6.2 was further chromatographed on silica gel CC, eluted with $\mathrm{CHCl}_{3}: \mathrm{MeOH}$ (from 10:1 to $1: 1, \mathrm{v} / \mathrm{v})$ to obtain eight subfractions (E6.2.1-8). At last, compound $2(20 \mathrm{mg})$ was obtained from subfraction EE6.2.2.

Similarly, subfraction EE7 was subjected on silica gel CC to collect subfraction EE7.7 and then was repeatedly purified by silica gel $\mathrm{CC}$ to obtain compound $\mathbf{3}$ (18 mg).

The $n$-butanol extract was subjected to a silica gel column and eluted with EtOAc: $\mathrm{MeOH}$ (from 100:1 to $10: 1, \mathrm{v} / \mathrm{v})$ to obtain seven fractions (BE1-7). Fraction BE7 was further separated on a silica gel $\mathrm{CC}$ and eluted with EtOAc: $\mathrm{MeOH}$ (from 50:1 to 0:100, v/v) to yield 12 subfractions (BE7.1-12). Subfraction BE7.8 was subjected repeatedly many times on silica gel CC to yield subfraction BE 7.8.4 and then further separation of this subfraction by silica gel CC gave compound $4(22 \mathrm{mg})$.

Compound 1 was obtained as a yellow powder, m.p. $216-218^{\circ} \mathrm{C}$.

${ }^{1}$ H-NMR (500 MHz, CD $\left.{ }_{3} \mathrm{OD}\right), \delta_{\mathrm{H}}(\mathrm{ppm}): 7.54(1 \mathrm{H}$, $\left.s, \mathrm{H}-2^{\prime}\right) ; 7.51\left(1 \mathrm{H}, d, 8.5 \mathrm{~Hz}, \mathrm{H}-6^{\prime}\right) ; 6.92(1 \mathrm{H}, d, 8.5$ $\left.\mathrm{Hz}, \mathrm{H}-5^{\prime}\right) ; 6.41(1 \mathrm{H}, s, \mathrm{H}-8) ; 6.23(1 \mathrm{H}, d, 8.5 \mathrm{~Hz}, \mathrm{H}-$ 6); $5.49\left(1 \mathrm{H}, s, \mathrm{H}-1^{\prime \prime}\right) ; 4.35\left(1 \mathrm{H}, d, 2.5 \mathrm{~Hz}, \mathrm{H}-2^{\prime \prime}\right)$; $3.92\left(1 \mathrm{H}, m, \mathrm{H}-4^{\prime \prime}\right) ; 3.89$ (1H, $\left.t, 4.5 \mathrm{~Hz}, \mathrm{H}-3^{\prime \prime}\right) ; 3.52$ (2H, $\left.m, \mathrm{H}-5^{\prime \prime}\right)$.

${ }^{13}$ C-NMR (125 MHz, CD $\left.{ }_{3} \mathrm{OD}\right), \delta_{\mathrm{C}}(\mathrm{ppm}): 180.0(\mathrm{C}-$ 4 ); 166.1 (C-7); 163.1 (C-5); 159.4 (C-2); 158.6 (C9); 149.9 (C-4'); 146.4 (C-3'); 134.9 (C-3); 123.1 $\left(\mathrm{C}-6^{\prime}\right) ; 123.0\left(\mathrm{C}-1^{\prime}\right) ; 116.9\left(\mathrm{C}-2^{\prime}\right) ; 116.5\left(\mathrm{C}-5^{\prime}\right)$; $109.6\left(\mathrm{C}-1^{\prime \prime}\right) ; 105.6$ (C-10); 99.9 (C-6); 94.8 (C-8); 88.1 (C-4"); 83.3 (C-2"); 78.7 (C-3"); 62.6 (C-5").

Compound $\mathbf{2}$ was obtained as light yellow crystals, m.p. $275-277^{\circ} \mathrm{C}$.

${ }^{1} \mathbf{H}-\mathbf{N M R}\left(500 \mathrm{MHz}, \mathrm{CD}_{3} \mathrm{OD}\right), \delta_{\mathrm{H}}(\mathrm{ppm}): 8.10(2 \mathrm{H}$, $\left.d, 9.0 \mathrm{~Hz}, \mathrm{H}-2^{\prime}, 6^{\prime}\right) ; 6.93\left(2 \mathrm{H}, d, 9.0 \mathrm{~Hz}, \mathrm{H}-3^{\prime}, 5^{\prime}\right)$; $6.41(1 \mathrm{H}, d, 2.5 \mathrm{~Hz}, \mathrm{H}-8) ; 6.20(1 \mathrm{H}, d, 2.0 \mathrm{~Hz}, \mathrm{H}-6)$.

${ }^{13}$ C-NMR (125 MHz, CD $\left.{ }_{3} \mathrm{OD}\right), \delta_{\mathrm{C}}(\mathrm{ppm}): 177.4(\mathrm{C}-$ 4); 165.6 (C-7); 162.5 (C-5); $160.6\left(\mathrm{C}-4^{\prime}\right) ; 158.3$ (C9); 148.1 (C-2); 137.1(C-3); 130.7 (C2', 6'); 123.8 (C-1'); 116.3 (C3', 5'); 104.6 (C-10); 99.3 (C-6); $94.5(\mathrm{C}-8)$.

Compound 3 was characterized as a colorless solid, m.p. $158-160^{\circ} \mathrm{C}$.

${ }^{1} \mathrm{H}-\mathrm{NMR}\left(500 \mathrm{MHz}, \mathrm{CD}_{3} \mathrm{OD}\right), \delta_{\mathrm{H}}(\mathrm{ppm}): 7.10(1 \mathrm{H}$, $s, \mathrm{H}-2) ; 7.10(1 \mathrm{H}, s, \mathrm{H}-6)$. 
${ }^{13}$ C-NMR (125 MHz, $\left.\mathrm{CD}_{3} \mathrm{OD}\right), \delta_{\mathrm{C}}(\mathrm{ppm}): 170.6(\mathrm{C}-$ 7); 146.4 (C-3,5); 139.5 (C-4); 122.3 (C-1); 110.3 $(\mathrm{C}-2,6)$.

Compound 4 was characterized as a light brown solid, m.p. $201-203^{\circ} \mathrm{C}$.

${ }^{1}$ H-NMR $\left(500 \mathrm{MHz}\right.$, acetone- $\left.d_{6}\right), \delta_{\mathrm{H}}(\mathrm{ppm}): 7.53$ $(1 \mathrm{H}, d, 2.0 \mathrm{~Hz}, \mathrm{H}-2) ; 7.48(1 \mathrm{H}, d d, 8.5$ and $2.0 \mathrm{~Hz}$, $\mathrm{H}-6) ; 6.90(1 \mathrm{H}, d, 8.5 \mathrm{~Hz}, \mathrm{H}-5)$;

${ }^{13}$ C-NMR (125 MHz, acetone- $\left.d 6\right)$ ), $\delta_{\mathrm{C}}(\mathrm{ppm}): 167.6$ (C-7); 150.7 (C-4); 145.6 (C-3); 123.6 (C-6); 123.1 (C-1); 117.5 (C-2); 115.7 (C-5).

\subsection{Antioxidant activity}

\subsubsection{DPPH assay}

In a 96-well microtiter plate, $50 \mu \mathrm{L}$ of each sample was added to $6 \times 10^{-5} \mathrm{M}$ methanol solution of DPPH. After mixing with a vortex mixer, the mixture was incubated for $30 \mathrm{~min}$ at room temperature and the absorbance was measured at $517 \mathrm{~nm}$. The DPPH radical scavenging activity was recorded as a percentage in comparison to the control. Vitamin C was used as a positive standard (Sharma et al., 2009).

\subsubsection{ABTS $^{*+}$ assay}

The free radical 2,2'-Azino-bis(3ethylbenzothiazoline-6-sulfonic acid $\left(\mathrm{ABTS}^{+*}\right)$ was produced by reacting ABTS solution in methanol (7 $\mathrm{mM}$ ) with aqueous potassium persulfate solution $(2.45 \mathrm{mM})$. The resulting mixture was allowed to stand in the dark for 12-16 hours before use. For aqueous extract ABTS was diluted with PBS (7.4 $\mathrm{pH})$ to an absorbance of $0.700 \pm 0.002$ at $734 \mathrm{~nm}$ and trolox (6-hydroxy-2,5,7,8-tetramethyl-2carboxylic acid) was used as standard for calibration curve (Nenadis et al., 2004)

\subsection{Statistical analysis}

The variation in a set of data has been estimated by performing one-way analysis of variance (ANOVA). Results were calculated from three independent experiments and repeated five times at each experiment, and are shown as mean $\pm \mathrm{SD}$, $\mathrm{n}=3$.

\section{RESULTS AND DISCUSSION}

\subsection{Structural elucidation}

The structures of isolated compounds were characterized by NMR spectra and by comparison with literature data.
The ${ }^{1} \mathrm{H}-\mathrm{NMR}$ data of compound $\mathbf{1}$ indicated that ring $\mathrm{A}$ is 5,7-disubstituted, as shown by two metalocated protons at $\delta_{\mathrm{H}}[6.41(1 \mathrm{H}, s, \mathrm{H}-8)$ and 6.23 $(1 \mathrm{H}, s, \mathrm{H}-6)]$. The observation of an $\mathrm{ABX}$ system at $\delta_{\mathrm{H}}\left[7.54\left(1 \mathrm{H}, s, \mathrm{H}-2^{\prime}\right), 7.51\left(1 \mathrm{H}, d, 8.5 \mathrm{~Hz}, \mathrm{H}-6^{\prime}\right)\right.$ and $\left.6.92\left(1 \mathrm{H}, d, 8.5 \mathrm{~Hz}, \mathrm{H}-5^{\prime}\right)\right]$ has suggested a $3^{\prime}, 4^{\prime}-$ disubstituted ring $\mathrm{B}$. A 3-O-substituted quercetin structures were indicated for compounds $\mathbf{1}$ due to the corresponding anomeric protons at $\delta_{\mathrm{H}} 5.49(1 \mathrm{H}$, $s)$ characteristic for arabinofuranosyl moiety. The structure of compound $\mathbf{1}$ was characterized as quercetin 3-O- $\alpha$-L-arabinofuranoside (avicularin) by comparison with literature data (Dawidar et al., 2014).

Compound 2 was isolated as yellow crystals, m.p. $275-277^{\circ} \mathrm{C}$. The ${ }^{1} \mathrm{H}-\mathrm{NMR}$ spectrum of compound 2 appeared four signals of six aromatic protons in which there were two couples of chemical shift equivalent protons with ortho-coupling signals at $\boldsymbol{\delta}_{\mathbf{H}}$ $[8.10(2 \mathrm{H}, \boldsymbol{d}, 9.0 \mathrm{~Hz})$ and $6.93(2 \mathrm{H}, d, 9.0 \mathrm{~Hz})]$; two meta-coupling signals at $\delta_{\mathrm{H}}[6.41(1 \mathrm{H}, d, 2.5 \mathrm{~Hz})$ and $6.20(1 \mathrm{H}, d, 2.0 \mathrm{~Hz})] .{ }^{13} \mathrm{C}-\mathrm{NMR}$ and DEPT spectra also exhibited signals of total 15 carbons of a flavone backbone. These carbons consisted of two signals of two couples of chemical shift equivalent carbons at $\delta_{\mathrm{C}} 116.3(2 \mathrm{C})$ and $130.7(2 \mathrm{C})$, related to two couples of chemical shift equivalent protons in its ${ }^{1} \mathrm{H}-\mathrm{NMR}$ spectrum. It proved that the fourhydroxyl substituted flavone had a symmetric aromatic ring. Moreover, the 1D-NMR spectral data of compound 2 were similar to those of kaempferol notified in the literature (Abdullah et al., 2012). From this evidence compound 2 was determined as 3,5,7,4'-tetrahydroxyflavone or kaempferol.

The chromatographic and physical properties along with NMR spectral data of compounds 3 and $\mathbf{4}$ were completely in agreement with the corresponding published data for gallic acid and protocatechuic acid (Khanh et al., 2016; Silva et al., 2015).

Four compounds 1-4 were isolated and identified from the leaves of Psidium guajava L., including avicularin (1), kaempferol (2), gallic acid (3) and protocatechuic acid (4) by analysis of their NMR spectra and HR-ESI-MS, and comparison with literature data (Figure 1). 
<smiles>O=c1c(O)c(-c2ccc(O)cc2)oc2cc(O)cc(O)c12</smiles><smiles>O=C(O)c1cc(O)c(O)c(O)c1</smiles><smiles>COc1cc(C(=O)O)ccc1O</smiles>

Figure 1. Chemical structures of compounds 1-4

\subsection{In vitro antioxidant activity results}

The free radical scavenging activities of isolated compounds were measured by DPPH and ABTS assays. The results are presented in Table 1. Ethyl acetate and $n$-butanol extracts of $P$. guajava $\mathrm{L}$. exhibited high scavenging potential with $\mathrm{IC}_{50}=$ $16.75 \mu \mathrm{g} / \mathrm{mL}$ and $15.64 \mu \mathrm{g} / \mathrm{mL} ; 11.76 \mu \mathrm{g} / \mathrm{mL}$ and $13.67 \mu \mathrm{g} / \mathrm{mL}$ for both DPPH and ABTS methods, respectively. All four isolated compounds exhibited the good ability of scavenging DPPH and ABTS radicals. Kaempferol exhibited the highest scavenging potential with $\mathrm{IC}_{50}=15.74 \mu \mathrm{g} / \mathrm{mL}$ and $13.09 \mu \mathrm{g} / \mathrm{mL}$ for DPPH and ABTS assays, respectively.

Table 1. IC I $_{50}$ values of fractionated extracts and isolated compounds

\begin{tabular}{lrr}
\hline $\begin{array}{l}\text { Extracts and } \\
\text { isolated } \\
\text { compounds }\end{array}$ & \multicolumn{2}{c}{$\mathbf{I C}_{\mathbf{5 0}}(\boldsymbol{\mu g} \mathbf{g} \mathbf{m L})$} \\
\cline { 2 - 3 } DPPH & ABTS \\
\hline -Hexane extract & $368.62 \pm 33.15$ & $357 \pm 28.18$ \\
$n$-Butanol extract & $16.75 \pm 2.75$ & $15.64 \pm 3.75$ \\
Methanol extract & $20.83 \pm 3.15$ & $24.37 \pm 3.85$ \\
Avicularin & $20.64 \pm 1.35$ & $22.83 \pm 0.72$ \\
Kaempferol & $15.74 \pm 11.29$ & $13.09 \pm 5.87$ \\
Gallic acid & $21.88 \pm 4.73$ & $18.43 \pm 3.22$ \\
Protocatechuic acid & $19.09 \pm 2.68$ & $14.47 \pm 0.32$ \\
Vitamin C & $3.82 \pm 0.74$ & - \\
Trolox & - & $3.47 \pm 0.07$ \\
\hline
\end{tabular}

Antioxidant substrates from plants may offer resistance against the oxidative stress by scavenging free radicals, inhibiting lipid peroxidation, and by other mechanisms. Natural antioxidant defense systems protect biomolecules against reactive oxygen species (ROS) induced damage. This protective effect can be enhanced by the use of antioxidant micronutrients (vitamins $\mathrm{C}$ and $\mathrm{E}, \beta$ carotene), and by non-nutrient ingredients like phenolic and flavonoid compounds from plants.
A number of studies have demonstrated a correlation between the antioxidant effect and the structures of flavonoids and phenolic compounds. Polyphenolic compounds have received extensive attention because of their beneficial physiological role, including antioxidant, antimutagenic, and for other diseases caused by oxidative stress. The phenolic compounds are very important plant constituents because of their scavenging ability due to their hydroxyl groups. Flavonoids are a large group of ubiquitous molecules and possess antioxidant activities (Heim et al., 2002; Seyoum et al., 2006). The present study found a correlation between the isolated flavonoids as well as phenolic compounds and the antioxidant activity. These results revealed that the leaves of Psidium guajava L. has a powerful antioxidant activity and might be a good candidate for development as a novel natural antioxidant.

\section{CONCLUSION}

The results of this study revealed that from the leaves of Psidium guajava L., grown in Vinh Long city, four compounds have isolated and identified: avicularin (1), kaempferol (2), gallic acid (3), and protocatechuic acid (4). The structures of these compounds have been elucidated by modern spectroscopic method NMR and in comparison with the literature data. Furthermore, the antioxidant potentials of fractioned extracts and four isolated compounds were also evaluated through the DPPH and ABTS assays. The results indicated that ethyl acetate and $n$-butanol extracts have good antioxidant activities and all isolated compounds exhibited the ability of scavenging DPPH and ABTS radicals.

\section{ACKNOWLEDGEMENT}

Our research team is very grateful for the financial support from Can Tho University for this study (Code: TSV2021-46). 


\section{REFERENCES}

Abdullah, N. H., Salim, F., \& Ahmad, R. (2016). Isolation of flavonols from the stems of Malaysian Uncaria cordata var. Ferruginea (Blume) RIDSD. Malaysian Journal of Analytical Sciences, 20(4), 844-848. https://doi.org/10.17576/mjas-2016-2004-18

Barbalho, S. M., Farinazzi-Machado, F. M. V., de Alvares Goulart, R., Brunnati, A. S., Otoboni, A. M., \& Ottoboni, B. (2012). Psidium guajava (Guava): A plant of multipurpose medicinal applications. Medicinal and Aromatic Plants Research Journals, 1(4), 1-6. http://dx.doi.org/10.4172/2167-0412.1000104

Biswas, B., Rogers, K., McLaughlin, F., Daniels, D., \& Yadav, A. (2013). Antimicrobial activities of leaf extracts of guava (Psidium guajava L.) on two Gram-negative and Gram-positive bacteria. International Journal of Microbiology, 2013, 1-7. https://doi.org/10.1155/2013/746165

Dawidar A., Abdel-Mogib M., El-Naggar M., \& Mostafa M. (2014). Isolation and characterization of Polygonum equisetiforme flavonoids and their acaricidal activity against Tetranychus urticae Koch, Research Journal of Pharmaceutical, Biological and Chemical Sciences, 5(4), 140-148. https://doi.org/10.7753/IJSEA0405.1018

Heim, K. E., Tagliaferro, A. R., \& Bobilya, D. J. (2002). Flavonoid antioxidants: chemistry, metabolism and structure-activity relationships. The Journal of Nutritional Biochemistry, 13(10), 572-584. https://doi.org/10.1016/S0955-2863(02)00208-5

Khanh, P. N., Đuc, H. V., Huong, T. T., Ha, V. T., Van, D. T., Kim, Y. H., \& Cuong, N. M. (2016). Phenolic compounds from Callistemon citrinus leaves and stems. Vietnam Journal of Science and Technology, 54(2), 190-197. https://doi.org/10.15625/0866-708X/54/2/6469

Mahfuzul Hoque, M. D., Bari, M. L., Inatsu, Y., Juneja, V. K., \& Kawamoto, S. (2007). Antibacterial activity of guava (Psidium guajava L.) and neem (Azadirachta indica A. Juss.) extracts against foodborne pathogens and spoilage bacteria. Foodborne Pathogens and Disease, 4(4), 481-488. https://doi.org/10.1089/fpd.2007.0040

Ngbolua, J. P. K. T. N. (2018). A review on the phytochemistry and pharmacology of Psidium guajava L. (Myrtaceae) and future direction. Phytomedicine, 5(2), 7-13. https://doi.org/10.15562/phytomedicine.2018.58

Naseer, S., Hussain, S., Naeem, N., Pervaiz, M., \& Rahman, M. (2018). The phytochemistry and medicinal value of Psidium guajava (guava). Clinical Phytoscience, 4(1), 1-8. https://doi.org/10.1186/s40816-018-0093-8

Nenadis, N., Wang, L. F., Tsimidou, M., \& Zhang, H. Y. (2004). Estimation of scavenging activity of phenolic compounds using the ABTS•+ assay. Journal of Agricultural and Food Chemistry, 52(15), 46694674. https://doi.org/10.1021/jf0400056

Rawi, S. M., Mourad, I. M., \& Sayed, D. A. (2011). Biochemical changes in experimental diabetes before and after treatment with mangifera indica and Psidium guava extracts. International Journal of Pharmacy and Biological Sciences, 2(2), 29-41.

Sharma, O. P., \& Bhat, T. K. (2009). DPPH antioxidant assay revisited. Food Chemistry, 113(4), 1202-1205. https://doi.org/10.1016/j.foodchem.2008.08.008

Silva da L. A. L., Faqueti L. G., Reginatto F. H., dos Santos A. D. C., Barison A., \& Biavatti M. W. (2015). Phytochemical analysis of Vernonanthura tweedieana and a validated UPLC-PDA method for the quantification of eriodictyol, Revista Brasileira de Farmacognosia, 25(4), 375-381. https://doi.org/10.1016/j.bjp.2015.07.009

Seyoum, A., Asres, K., \& El-Fiky, F. K. (2006). Structure-radical scavenging activity relationships of flavonoids. Phytochemistry, 67(18), 2058-2070. https://doi.org/10.1016/j.phytochem.2006.07.002 